\title{
Forecasting the Export Energy Policy of Russia in Terms of Volatility of World Prices on Resources
}

\author{
Rodnyansky D.V.a \\ Yasnitskaya Y.S. ${ }^{b}$ \\ ${ }^{a b}$ Kazan Federal University, Institute of Management, Economics and Finance, Kazan, 420008, Russia \\ Email: drodnyansky@gmail.com.
}

\section{Doi:10.5901/mjss.2015.v6n1s3p313}

\begin{abstract}
Forecasting the export energy policy is an important tool for creating Russia's development strategy for the long term. The dependence of the budget on energy prices makes us look for new and more effective methods of assessing and predicting the impact of internal and external risks to the domestic economy. In terms of volatility of international oil prices on the quality of the prediction depends on the stability and balance of revenues and expenditures of the federal budget.
\end{abstract}

Keywords: oil market, forecasting, energy policy, export policy, volatility of resource prices

\section{Introduction}

The budgets of the largest exporting countries energy resources are largely dependent on macroeconomic indicators such as exchange-traded commodity prices, global economic growth, as well as the needs of the global economy in this commodity.

For this reason, in the economic literature, much attention is paid to the analysis of trends and prospects in the global oil and gas markets, as well as the calculation of risks and potential losses from price deviations from the targets. In this approach, economists differ significantly. Several scientists analyze the oil market in the first place from the position of the concept of asymmetric information $[1,2]$. Other authors are developing various scenarios of the situation on the commodity markets through a variety of econometric models and techniques of risk management $[3,4,5,6]$. Some authors recognize the central role Exporting Countries, OPEC, particularly Saudi Arabia, and urged making forecasts based on the analysis of socio-economic development of the country [7]. We can also highlight the research that argues that trends and movements in global commodity prices is the basis of the interaction of traditional and spot markets [8].

We can also mention the concept of forecasting commodity prices in real time on the basis of detailed analysis of volatility over the last 20 years [9]. For Russia, the issue of quality and comprehensive forecasting of energy prices for Russia is also very actual, and some works of Russian scientists are devoted to this problem [10,11,12].

\section{Theory}

Prediction of long-term socio-economic development of the Russian Federation for the period up to 2030 - is one of the most important documents of the Russian economy. This paper describes the main directions of development of the economy, as well as the expected results. Based on the long-term prognosis is developing a strategy targeted programs, and other planning documents.

In the long-term prognosis there are considered three scenarios:

- Conservative;

- Innovation;

- Target (formable).

Conservative scenario (Option 1) is characterized by moderate long-term growth of the economy on the basis of active modernization of fuel, energy and raw materials sectors, while maintaining the relative backlog in civil high- and medium-tech sectors.

In the conservative scenario modernization of the economy will focus mainly on foreign technology and knowledge. Innovation scenario (option 2) is characterized by increased investment focus of economic growth. The script is 
based on the creation of a modern transport infrastructure and competitive sector of high-tech industries and knowledge economy, along with the modernization of raw complex.

Target (forced) scenario (option 3) is designed based on the innovation scenario, while it is characterized by forced growth, increased private savings and the creation of a powerful export sector products with high added value.

Scenario A - low oil prices (less than $\$ 80$. Per barrel).

Scenario $\mathrm{C}$ - high oil prices (more than $\$ 80$. Per barrel).



Fig 1. Export of oil, million tons

Figure 1 shows the scenarios of oil exports. Scenarios 3 and $C$ coincide.

Let's consider a scenario in terms of low oil prices. Exports will decline quite rapidly. In 2010, exports amounted to 251 million. tons, in 2015 exports fell by 19 million and reach 232 million tons. By 2030, exports will be below 200 million tons - 186 million tons, which is almost a third lower than the 2010 level.

Data for the conservative and innovative scenarios are identical. Exports will fluctuate. In 2015, there will be a decrease in the volume of exports, but exports in 2020 will be increased by 10 million tons, and then again followed by a decline.

Compared with the export of oil, natural gas exports will grow under all conditions. According to the conservative scenario in 2030 the export of natural gas will be 238 BCM, up 50 BCM more than was exported in 2010. According to forced scenario exports compared to 2010 will increase by 79 BCM. The highest rates of growth in export volumes of natural gas will be at innovative development of the economy (Figure 2).

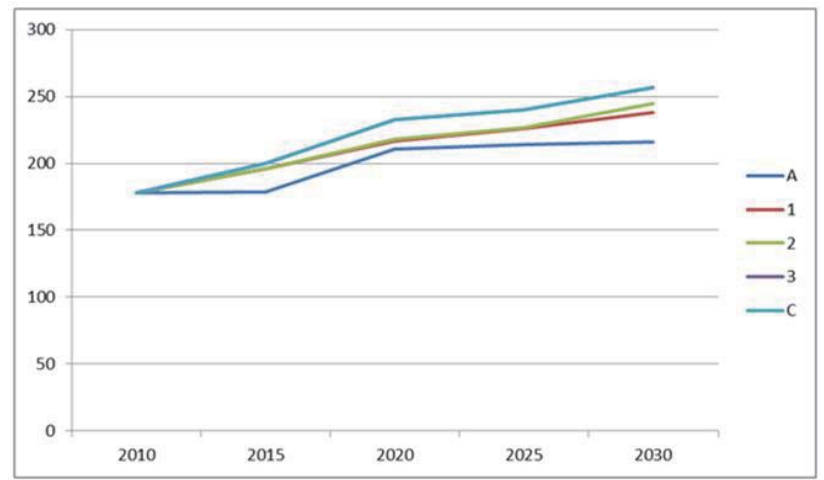

Fig 2. Export of natural gas (pipeline), BCM

\section{Results}

Based on analysis of long-term forecast, we can make the following conclusions:

- Export of petroleum products will decline;

- Exports of natural gas will increase in all scenarios considered;

- Export and production of oil will rise or fall depending on the scenario development;

- Production of gas (natural) will increase in all scenarios.

We can forecast the volume of mineral products in foreign trade in the medium term with the help of regression analysis. For the analysis we use the data of the Federal State Statistics Service from 2000 to 2012. 
Used for the regression analysis data are shown in Table 1.

Table 1. The main parameters of oil and gas industry (2000-2012)

\begin{tabular}{|c|c|c|c|c|c|c|c|c|c|}
\hline & $\begin{array}{c}\mathrm{y} \\
\text { Volume of mine- } \\
\text { eral products in } \\
\text { exports as } \% \text { of } \\
\text { total }\end{array}$ & $\begin{array}{l}\text { x1 } \\
\text { Average export } \\
\text { prices for crude } \\
\text { oil (US. Dollars } \\
\text { per ton) }\end{array}$ & $\begin{array}{c}\text { x2 } \\
\text { average } \\
\text { export prices } \\
\text { for natural gas, } \\
\text { for } 1000 \mathrm{m3}\end{array}$ & $\begin{array}{c}\text { х3 } \\
\text { Средние } \\
\text { экспортные } \\
\text { цены на } \\
\text { несттепродукты } \\
\text { (долл. США за } \\
\text { тонну) }\end{array}$ & \begin{tabular}{|c|}
$\mathrm{x} 4$ \\
Average \\
export prices \\
of petroleum \\
products (US. \\
Dollars per \\
ton)
\end{tabular} & $\begin{array}{c}\text { x5 } \\
\text { Extraction } \\
\text { of natural } \\
\text { gas, bln. } \\
\text { M3 }\end{array}$ & $\begin{array}{l}\text { x6 } \\
\text { Exports } \\
\text { of crude } \\
\text { oil, mln. } \\
\text { tons }\end{array}$ & $\begin{array}{c}\text { x7 } \\
\text { Exports } \\
\text { of natural } \\
\text { gas, bln. } \\
\text { M3 }\end{array}$ & \begin{tabular}{l}
\multicolumn{1}{c}{$\mathrm{x} 8$} \\
Exports of \\
petroleum \\
products, \\
mln. Tons
\end{tabular} \\
\hline 2000 & 53,8 & 175 & 85,9 & 174 & 324 & 555 & 145 & 194 & 62,7 \\
\hline 2001 & 54,7 & 151 & 101 & 148 & 348 & 551 & 162 & 181 & 63,5 \\
\hline 2002 & 55,2 & 154 & 85,7 & 149 & 380 & 563 & 188 & 186 & 75,4 \\
\hline 2003 & 57,3 & 174 & 106 & 181 & 421 & 581 & 223 & 189 & 77,7 \\
\hline 2004 & 57,8 & 226 & 109 & 234 & 459 & 591 & 258 & 200 & 82,4 \\
\hline 2005 & 64,8 & 330 & 151 & 348 & 470 & 598 & 253 & 207 & 97,1 \\
\hline 2006 & 65,9 & 412 & 216 & 429 & 481 & 612 & 248 & 203 & 104 \\
\hline 2007 & 64,9 & 470 & 234 & 465 & 491 & 604 & 258 & 192 & 112 \\
\hline 2008 & 69,8 & 663 & 354 & 676 & 488 & 613 & 243 & 195 & 118 \\
\hline 2009 & 67,4 & 407 & 249 & 387 & 494 & 527 & 247 & 168 & 124 \\
\hline 2010 & 68,5 & 546 & 273 & 529 & 506 & 593 & 247 & 174 & 133 \\
\hline 2011 & 71,1 & 744 & 343 & 727 & 512 & 612 & 244 & 187 & 132 \\
\hline 2012 & 71,4 & 754 & 348 & 750 & 519 & 592 & 240 & 179 & 138 \\
\hline
\end{tabular}

After we calculated the correlations between the independent and dependent variables, we will leave 3 important indicators- $x 2$ - the average actual export prices for natural gas; $x 7$ - exports of natural gas; $x 8$ - exports of petroleum products. The coefficient of determination $\mathrm{R}^{2}=98,1 \%$, which means that it is the high quality model.

On the basis of the regression analysis form the equation type $y=a x+b$.

$y=23,248+0,019^{*} x 2+0,093^{*} \times 7+0,183^{*} \times 8$

This equation is necessary to predict the volume of mineral products in foreign trade.

Substituting in this equation the values of $x$, and we get the forecast for the next five years (Table 2).

Table 2. Forecasting of volumes of mineral products in exports by 2018.

\begin{tabular}{|c|c|c|c|c|}
\hline & $\begin{array}{c}\text { Volume of mine-eral prod-ucts in } \\
\text { exports as\% of total }\end{array}$ & $\begin{array}{c}\text { X2 } \\
\text { average export prices for natural } \\
\text { gas, for } 1000 \mathrm{m3}\end{array}$ & $\begin{array}{c}\mathbf{X} \text { ( } \\
\text { Exports of natu-ral } \\
\text { gas, bln. M3 }\end{array}$ & $\begin{array}{c}\text { X8 } \\
\text { Exports of petro-leum prod- } \\
\text { ucts, mln. Tons }\end{array}$ \\
\hline 2000 & 53,8 & 85,9 & 194 & 62,7 \\
\hline 2001 & 54,7 & 101 & 181 & 63,5 \\
\hline 2002 & 55,2 & 85,7 & 186 & 75,4 \\
\hline 2003 & 57,3 & 106 & 189 & 77,7 \\
\hline 2004 & 57,8 & 109 & 200 & 82,4 \\
\hline 2005 & 64,8 & 151 & 207 & 97,1 \\
\hline 2006 & 65,9 & 216 & 203 & 104 \\
\hline 2007 & 64,9 & 234 & 192 & 112 \\
\hline 2008 & 69,8 & 354 & 195 & 118 \\
\hline 2009 & 67,4 & 249 & 168 & 124 \\
\hline 2010 & 68,5 & 273 & 174 & 133 \\
\hline 2011 & 71,1 & 343 & 187 & 132 \\
\hline 2012 & 71,4 & 348 & 179 & 138 \\
\hline 2013 & 74,6 & 378 & 181 & 149 \\
\hline 2014 & 76,3 & 403 & 180 & 156 \\
\hline 2015 & 77,9 & 428 & 179 & 163 \\
\hline 2016 & 79,5 & 453 & 178 & 170 \\
\hline 2017 & 81,1 & 478 & 177 & 177 \\
\hline 2018 & 82,8 & 504 & 176 & 183 \\
\hline
\end{tabular}




\section{Conclusions}

Thus, we can conclude that, regardless of changes in energy prices and the absence of significant external shocks volume of mineral products in Russia's foreign trade will increase by an average of 1.5\% per year, reaching in 2018 82\% of the total volume of goods that Russia exports.

The analysis does not allow to evaluate the factor of geopolitical instability, released to the fore in 2014, as a result of which the price of oil dropped to the lowest level during the last 5 years. However, the scenario of high oil prices estimated price of a barrel from $\$ 80$, and the scenario of low prices- less than 80 dollars. That is the least likely course of events, as most experts predict the price of oil is in the range from 80 to 100 dollars per barrel.

However, it appears that in the medium-term impact of foreign threats will have no significant impact on the performance of the commodity complex in Russia, especially in connection with the conclusion of the contract with the Chinese People's Republic and the start of the world's largest construction project of a gas pipeline.

\section{References}

Venditti, F. From oil to consumer energy prices: How much asymmetry along the way?// Energy Economics.- Volume 40, November 2013, Pages 468-473

A real threat to oil markets//Petroleum Economist.- Volume 79, Issue 2, March 2012, $4 p$

Haugom, E., Langeland, H., Molnár, P., Westgaard, S. Forecasting volatility of the U.S. oil market// Journal of Banking and Finance.Volume 47, Issue 1, October 2014, Pages 1-14

Chkili, W., Hammoudeh, S., Nguyen, D.K. Volatility forecasting and risk management for commodity markets in the presence of asymmetry and long memory//Energy Economics.- Volume 41, January 2014, Pages 1-18

Chen, S.-S. Forecasting crude oil price movements with oil-sensitive stocks//Economic Inquiry.- Volume 52, Issue 2, April 2014, Pages 830-844

Kang, W., Ratti, R.A. Structural oil price shocks and policy uncertainty//Economic Modelling.- Volume 35, September 2013, Pages 314319

Mensi, W., Hammoudeh, S., Yoon, S.-M. Structural breaks and long memory in modeling and forecasting volatility of foreign exchange markets of oil exporters: The importance of scheduled and unscheduled news announcements//International Review of Economics and Finance.- Volume 30, March 2014, Pages 101-119

Chen, P.-F, Lee, C.-C., Zeng, J.-H. The relationship between spot and futures oil prices: Do structural breaks matter?// Energy Economics.- Volume 43, May 2014, Pages 206-217

Gallyamova D. Kh. Development of Globalization in the Modern Economy // World Applied Sciences Journal 30 (9): 1160-1165, 2014

Nurieva, A.R., Gibadullin, M.Z., Fazlieva, E.P. Stability of interregional trade and economic relations as the factor of competitiveness of territories, World Applied Sciences Journal, Volume 29, Issue 4, 2014, Pages 501-505

Baumeister, C., Kilian, L. Real-time forecasts of the real price of oil//Journal of Business and Economic Statistics.- Volume 30, Issue 2, 2012, Pages 326-336

Glebova, I., Khabibrakhmanova, R., Yasnitskaya, Y. The analysis of the impact of the investment attractiveness factors of the region on the fixed capital investments in the economy of the Republic of Tatarstan // Middle East Journal of Scientific Research 17 (10), pp. 1498-1502,-2014.

Gibadullin, M.Z., Fazlieva, E.P., Nurieva, A.R., Grigoryeva, L.L. Territorial aspects of migration processes in Russia. Mediterranean Journal of Social Sciences, Volume 5, Issue 12, June 2014, Pages 93-96.

Abramova, E., Apokin, A., Belousov, D., Mikhailenko, K., Penukhina, E., Frolov, A. Future of Russia: Macroeconomic scenarios in the global context//Foresight Russia.- Volume 7, Issue 2, 2013, Pages 6-25

Glebova I.S., Yasnitskaya Ya.S., Maklakova N.V. Possibilities of "Smart City" Concept Implementing: Russia' s Cities Practice/l Mediterranean Journal of Social Sciences.- Vol.5, No12, (2014)-pp.129 - 133. 